\title{
Prospects for $\mathrm{CO}_{2}$ carbonation and storage in Upper Miocene sandstone of Sava Depression, Croatia
}

\author{
Ena HUSANOVIĆ ${ }^{1}$, Karolina NOVAK ${ }^{2, *}$, Tomislav MALVIĆ 3,4 , \\ Kristina NOVAK ZELENIKA ${ }^{3}$ and Josipa VELIĆ ${ }^{4}$ \\ 4 University of Zagreb, Faculty of Mining, Geology and Petroleum Engineering, Pierottijeva 6, Zagreb, Croatia
}

1 Veselišće 2c, Zagreb, Croatia

2 INA-Industry of Oil Plc., Av. V. Holjevca 10, Zagreb, Croatia

3 INA-Industry of Oil Plc., Šubićeva 29, Zagreb, Croatia

Husanović, E., Novak, K., Malvić, T., Novak Zelenika, K., Velić., J., 2015. Prospects for $\mathrm{CO}_{2}$ carbonation and storage in Upper Miocene sandstone of Sava Depression, Croatia. Geological Quarterly, 59 (1): 91-104, doi: 10.7306/gq.1215

\begin{abstract}
Upper Miocene sandstones in the Sava Depression (Northern Croatia) are potential targets for carbon dioxide $\left(\mathrm{CO}_{2}\right)$-based enhanced oil recovery (EOR) processes or mineral carbonation with reservoir brine. In general, sandstone lithology, even rich with aluminosilicate minerals, is not the most favourable rock medium for efficient sequestration of $\mathrm{CO}_{2}$ in minerals. However, $\mathrm{CO}_{2}$ is naturally sequestered in minerals when $\mathrm{CO}_{2}$ is injected into sandstone reservoirs and subdued to carbonation. The timescale of such sequestration is on the order of $10^{4}-10^{5}$ years. Upper Miocene sandstones in the Sava Depression could incorporate up to $25 \%$ of aluminosilicate minerals ( $10 \%$ K-feldspars) and up to $20 \%$ dolomites and often laterally transition between pelitic and psammitic lithofacies, rich in clay minerals (15\% micas). Total volumes are approximately 107 and 62 million $\mathrm{m}^{3}$ (approximately 268 and 155 million t of rocks), respectively for the potential injection reservoirs in the Ivanić Field. Oil saturation in the injection intervals is estimated to be approximately 14.8 and 4.1 million $\mathrm{m}^{3}$ respectively. Geochemical analogies and mineralogy can be used to support predictions for the low percentages of injected $\mathrm{CO}_{2}$ that may be stored during carbonation and form secondary minerals.
\end{abstract}

Key words: carbon dioxide, carbonation, Miocene, sandstones, Sava Depression, Croatia.

\section{INTRODUCTION}

Carbon dioxide $\left(\mathrm{CO}_{2}\right)$ capture and storage (CCS) plays an increasingly important role in reducing $\mathrm{CO}_{2}$ emissions from human activities. It involves separation and compression of $\mathrm{CO}_{2}$ from industrial and power plants, and transportation to a storage site for long-term storage. The reaction between a metal oxide-bearing material and $\mathrm{CO}_{2}$ is called mineral carbonation and can be expressed by the reaction (Sipilä et al., 2008; Bodor et al., 2011) given by Equation 1:

$$
\mathrm{MO}+\mathrm{CO}_{2} \leftrightarrow \mathrm{MCO}_{3}+\text { heat }
$$

"In situ" mineral carbonation is closely connected to underground storage of $\mathrm{CO}_{2}$ injected into reservoirs or other favourable lithologies. Carbonation is a reaction between rock alkaline minerals and $\mathrm{CO}_{2}$ that results in the formation of carbonates.

\section{* Corresponding author, e-mail: karolina.novak@ina.hr}

Received: Received: July 3, 2014; accepted: December 30, 2014; first published online: January 26, 2015
The reaction [Equation 1] is exothermic and the heat released is dependent on the metallic element-bearing mineral. The major benefit of $\mathrm{CO}_{2}$ sequestration by mineral carbonation is that it is an environmentally benign process and ensures permanent trapping of $\mathrm{CO}_{2}$ in the form of carbonate minerals. Unlike other $\mathrm{CO}_{2}$ sequestration methods, all $\mathrm{CO}_{2}$ is fixed in minerals and results in a leakage-free sequestration that does not require post-storage monitoring (Bodor et al., 2011).

The energy released (e.g., heat/enthalpy change in Equation 1) in processes means that carbonation could proceed without energy input (which is why it occurs naturally). However, many of the carbonation processes presented to date suffer from being too energy demanding and the largest challenge is to enhance the otherwise extremely slow (on human time scale) carbonation reaction, without excessive overall process costs. Simply crushing metal oxide-bearing ore to particle sizes of $1 \mathrm{~mm}$ and suspending in aqueous 100\% dissolution can achieve what around 2,000 years of diagenesis may achieve (Hangx and Spiers, 2009; Bodor et al., 2011). Several elements can be carbonated due to their abundance and insolubility. For example, alkaline metals such as calcium and magnesium seem to be most suitable. Although iron shows good carbonation characteristics, it is a valuable mineral resource and, therefore, cannot be considered for large-scale carbonation im- 
plementations (Hujigen and Comans, 2005). However, iron-ore mining waste should be considered for mineral carbonation.

Minerals of interest, reaction energy, and the quantity required to sequester a unit weight of $\mathrm{CO}_{2}$ (assuming complete reaction of the mineral) are shown in Table 1 (Penner et al., 2004).

Mineral carbonation was first mentioned as a $\mathrm{CO}_{2}$ binding concept by Seifritz (1990). Since natural silicate minerals (such as olivine, serpentine, and wollastonite) and basalt rock were identified as the most suitable raw materials, research on mineral carbonation has accelerated and divided into several different $\mathrm{CO}_{2}$ binding approaches. Direct carbonation of the mineral takes place in a single process step, while indirect carbonation considers extraction of calcium or magnesium from the mineral and subsequent carbonation (Bodor et al., 2011).

The mineral mass necessary to bind unit mass of $\mathrm{CO}_{2}$ as carbonate is in the range $1.8-3 \mathrm{t}$ mineral/t $\mathrm{CO}_{2}$ for relatively pure minerals. This means that for a $500 \mathrm{MW}$ unit emitting 3.4 Mt/ann of $\mathrm{CO}_{2}$, approximately 6-10 Mt of mined or subsurface rock minerals would be required per year. The economics of mineral carbonation at scale are now being tested in a world-first pilot plant project in Newcastle, Australia (http://mineralcarbonation.com linked onto http://www.abc.net.au/news/2013-08-23//world-first-pilot-plant-will-turn-carbon-dioxide-into-rock/4908324).

\section{$\mathrm{CO}_{2}$ SEQUESTRATION DURING PROCESS OF CARBONATION AND STORAGE IN SECONDARY ROCK MINERALS}

The International Energy Agency, Greenhouse Gas Protocol programme (IEA GHG; http://www.ghgprotocol.org/ThirdParty-Databases/IEA-GHG-Programme) published a technology valuation in 2000 that refers to seven processing routes and concluded that all involved high costs and excessive energy use. Additionally, the indirect process routes gave the benefit of much faster carbonation chemistry. Studies at the Los
Alamos National Laboratory in the USA (Lackner et al., 1997) stated that gas-solid carbonation at higher temperature and pressure $\left(500^{\circ} \mathrm{C}, 340\right.$ bars) reached $25 \%$ mineral conversion after 2 hours with $100 \mathrm{~mm}$ serpentine particles. Further research, for example in Finland (Zevenhoven and Kohlmann, 2002), showed reaction kinetics for the gas-solid carbonation case, that can be compared with direct aqueous processes developed by the Albany Research Centre in the USA using $\mathrm{NaHCO}_{3}$ and $\mathrm{NaCl}$ at 150 bars and $155^{\circ} \mathrm{C}$ for serpentine (O'Connor et al., 2005). Since 2000, the carbonation of industrial wastes and by-products such as steel slag, waste cement or concrete and ashes, which often contain significant amounts of calcium that can be carbonated, has also received growing attention.

Different process conditions can be applied, depending on the type of raw material used for the direct carbonation process, with optimal carbonation conditions shown in Table 2 (Gerdemann et al., 2007). Reasonable reaction times and conversion efficiencies are allowed by high pressures (the supercritical pressure of $\mathrm{CO}_{2}$ at average atmospheric temperature is approximately 79 bars), but such aggressive process conditions suggest relatively high technical and economic risk.

It is well-known that reaction rates are enhanced by increasing the reaction temperatures. However, stability of a carbonate is constrained by thermodynamic conditions and, therefore, the temperature can only be increased to a certain level (pressure dependent). For example, $\mathrm{MgCO}_{3}$ is stable up to temperatures of around $400^{\circ} \mathrm{C}$ at $\mathrm{CO}_{2}$ pressures of 1 bar (Zevenhoven et al., 2006). Therefore, use of exothermic high temperature carbonation on enough "high fast reaction rates" would not work without pressurisation.

Sipilä et al. (2008) state that the direct aqueous mineral-carbonation route appears to be the most promising $\mathrm{CO}_{2}$ mineralisation alternative to date, but despite high carbonation degrees and acceptable rates achieved in the process, it is still too expensive to be applied on a large scale. Expensive pre-treatment steps aimed at accelerating the reaction rates must be im-

Minerals of interest for mineral carbonation (Penner et al., 2004)

\begin{tabular}{|l|c|c|c|}
\hline \multicolumn{1}{|c|}{ Mineral } & Formula & $\begin{array}{c}\text { Products of complete } \\
\text { reaction with } \mathrm{CO}_{2}\end{array}$ & $\left.\begin{array}{c}\text { Mineral requirement } \\
{[\mathrm{kg} / \mathrm{kg} \mathrm{CO}}\end{array}\right]$
\end{tabular}

Process conditions for optimum direct carbonation of minerals (Zevenhoven et al., 2007)

\begin{tabular}{|l|c|c|c|c|}
\hline \multicolumn{1}{|c|}{ Mineral } & $\begin{array}{c}\text { Temperature } \\
{\left[{ }^{\circ} \mathrm{C}\right]}\end{array}$ & $\begin{array}{c}\text { Pressure of } \mathrm{CO}_{2} \\
{[\mathrm{~b} \text { bars }]}\end{array}$ & Additive solution & $\begin{array}{c}\text { Carbonation after } \\
\text { one hour [\%] }\end{array}$ \\
\hline Olivine & 185 & 150 & $\begin{array}{c}0.64 \mathrm{M} \mathrm{NaHCO} \\
\mathrm{NaCl}\end{array}$ & 49.5 \\
\hline Wollastonite & 100 & 40 & water & 81.8 \\
\hline Serpentine & 155 & 115 & $0.64 \mathrm{M} \mathrm{NaHCO}{ }_{3} 1 \mathrm{M}$ & 73.5 \\
\hline
\end{tabular}


proved or bypassed to make direct aqueous mineral-carbonation competitive with other CCS technologies.

Application of previous ex situ studies to in situ mineral sequestration could lead to promising results. The next logical step is to apply these reactions in situ where rock depth $(\sim 1 \mathrm{~km})$ could provide sufficient heat and pressure to drive the reaction, and reaction time is no longer such a critical factor ( $O$ 'Connor et al., 2001).

McKelvy et al. (2006) investigated in situ carbonation conditions with reaction systems that enable control of a wide variety of process conditions. Hansen et al. (2005) also studied "in situ" mineral reactions associated with listwanite (i.e. rock type that forms when ultramafic rocks, mostly peridotites, are completely carbonated) and found that carbonation minimizes porosity loss and maximizes permeability. This could be achieved using a $\mathrm{CO}_{2}$-enriched aqueous fluid. Yajima et al. (2006) studied the reactions of serpentinite subjected to $\mathrm{CO}_{2}$ pressure of 10 bars for 8 days at $50^{\circ} \mathrm{C}$. The experiments resulted in rock carbonate ratios of 1.7-10 vol. \% in the form of $\mathrm{FeCO}_{3}$ with $25 \%$ magnesium. Conversion led to a $\mathrm{CO}_{2}$ fixation rate of $1.4-5.4 \times 10^{-9} \mathrm{~mol}$ $\mathrm{CO}_{2} / \mathrm{cm}^{2}$ per day, that exhibited potential to sequester $\mathrm{CO}_{2}$ in serpentinite rock (Sipilä et al., 2008). Table 3 shows the main carbonation routes with a brief description and, to recapitulate; various process routes have been developed through numerous experiments. Many of the process routes have been abandoned, but research, especially on aqueous mineral carbonation, has continued.

There are also several other published studies dealing with $\mathrm{CO}_{2}$ sequestration by mineral trapping in sandstone formations. For instance, according to Xu et al. $(2004,2008)$ sequestration of $\mathrm{CO}_{2}$ in the sandstone layers results in formation of dawsonite $\left[\mathrm{NaAlCO}_{3}(\mathrm{OH})_{2}\right]$ and ankerite $\left[\left(\mathrm{CaMg}_{0.3} \mathrm{Fe}_{0.7}\left(\mathrm{CO}_{3}\right)_{2}\right]\right.$. Siderite initially precipitated, but after its dissolution, ankerite forms. Results of numerical modelling of $\mathrm{CO}_{2}$ sequestration in clayey sandstone aquifers (Xu et al., 2004) showed that mineral trapping increased sequestration capacity for 40,000 years, after which it decreases. Mineral trapping storage capacity reached an average value of $90 \mathrm{~kg} / \mathrm{m}^{3}$. Numerical modelling of pure $\mathrm{CO}_{2}$, or its mixture with $\mathrm{SO}_{2}$ and $\mathrm{H}_{2} \mathrm{~S}$ injection, resulted in the creation of concentric zones of secondary minerals in the area around the injection boreholes (Xu et al., 2008). The injection of a mixture of $\mathrm{CO}_{2}$ and $\mathrm{SO}_{2}$ formed larger zones, but with no significantly different alternations. The precipitation of car- bonate occurred in the peripheral area $(\mathrm{pH}>5)$, and significant amounts of $\mathrm{CO}_{2}$ were sequestered in ankerite, dawsonite, and siderite. Secondary sulphates deposited in a zone of $\mathrm{pH}<5$, and most of the injected $\mathrm{SO}_{2}$ was transformed and immobilized in alunite, anhydrite, and pyrite.

\section{PREVIOUS RESEARCH OF $\mathrm{CO}_{2}$ STORAGE IN THE SAVA DEPRESSION UPPER MIOCENE SANDSTONE RESERVOIRS}

Continued analyses of sandstone reservoirs inside the field structures are warranted for two main reasons:

- the hydrocarbon fields have been more thoroughly explored than areas among them (i.e., greater number of data points);

- the most permeable and pure sandstone lithologies in the Croatian part of the Pannonian Basin System are, due to tectonics of the 2nd transpressional period, uplifted into anticlines and saturated with hydrocarbons.

Research was conducted in the period between 1978 and 1998 to examine the possibility of applying the EOR methods in the Croatian hydrocarbon fields. Applicability of the process in some oil reservoirs is defined by:

- significant reduction in oil and increment of water viscosity;

- change in oil and water density;

- swelling and evaporation of oil;

_ increased permeability of the reservoir rocks;

- changes in rock wetting;

- possible occurrence of dissolved gas regime (e.g., Sečen, 2006; Al-Jarba and Al-Anazi, 2009).

Miscible conditions completely overcome capillary forces that retain residual oil in the pore space. Establishment of the miscible zone depends on pressure, temperature, reservoir rock, and crude oil composition (e.g., Taber et al., 1997). Results of such laboratory tests (Goričnik and Domitrović, 2003; Perić and Kovač, 2003) in several Croatian oil fields are shown in Table 4. Detailed laboratory analytical conditions used for samples from the Ivanić Field are given in Figure 1. The first simulation curve (Fig. 1, case A) shows continuous injection of

Main carbonation process routes (modified with data from Sipilä et al., 2008)

\begin{tabular}{|c|c|c|c|c|c|}
\hline DIRECT & \multicolumn{4}{|c|}{ INDIRECT } & OTHER \\
\hline $\begin{array}{l}\text { Simplest approach, } \\
\text { suitable for feedstock } \\
\text { carbonated in a single } \\
\text { process step or for } \\
\text { mineralisation into }\end{array}$ & \multicolumn{4}{|c|}{$\begin{array}{l}\text { Process is divided into two steps: } \\
\text { - reactive component ( } \mathrm{Mg} \text { or } \mathrm{Ca}) \text { are first extracted from the feedstock } \\
\text { (as oxide or hydroxide); } \\
\text { - it is reacted with carbon dioxide to form the desired carbonates }\end{array}$} & $\begin{array}{l}\text { Processes that } \\
\text { could be } \\
\text { considered but } \\
\text { are highly theoret- } \\
\text { ical and with } \\
\text { lacking }\end{array}$ \\
\hline $\begin{array}{l}\text { Gaseous } \mathrm{CO}_{2} \text { and solid } \\
\text { minerals (dry process) }\end{array}$ & Aqueous & Multistage gas-solid & Acetic acid route & $\begin{array}{l}\text { Two-step } \\
\text { aqueous }\end{array}$ & \\
\hline $\begin{array}{c}\text { Reactions between metal } \\
\text { oxide and } \mathrm{CO}_{2} \text {. } \\
\text { Potential of producing high } \\
\text { temperature steam } \\
\text { or electricity. } \\
\text { Disadvantages are too slow, } \\
\text { thermodynamic limitations } \\
\text { and unviable for industrial } \\
\text { purposes. }\end{array}$ & $\begin{array}{c}\text { The most } \\
\text { promising } \mathrm{CO}_{2} \\
\text { mineralisation } \\
\text { alternative to } \\
\text { date. Process } \\
\text { also possible } \\
\text { into subsurface } \\
\text { rocks }\end{array}$ & $\begin{array}{l}\text { Carbonation of } \mathrm{Mg}(\mathrm{OH})_{2} \\
\text { faster than MgO; } \\
\text { process divide into } \\
\text { three-steps: } \\
\text { - MgO production in an at- } \\
\text { mospheric reactor, } \\
\text { - MgO hydration, } \\
\text { - carbonation at elevated } \\
\text { pressures }\end{array}$ & $\begin{array}{l}\text { Two-step carbon- } \\
\text { ation: } \\
\text { use of acetic acid } \\
\text { for the extraction } \\
\text { of calcium from } \\
\text { a calcium-rich } \\
\text { feedstock }\end{array}$ & $\begin{array}{l}\text { Overall } \\
\text { reaction di- } \\
\text { vided into } \\
\text { two-steps, i.e. } \\
\text { extraction } \\
\text { and } \\
\text { precipitation }\end{array}$ & $\begin{array}{l}\text { Subsurface } \\
\text { brines, } \\
\text { accelerated } \\
\text { weathering of } \\
\text { limestone }\end{array}$ \\
\hline
\end{tabular}


Results of laboratory research on the possibility of establishing miscible conditions for several Croatian oil fields (Sečen, 2006)

\begin{tabular}{|c|c|c|c|c|c|c|c|c|c|c|c|}
\hline \multirow[b]{2}{*}{ Field } & \multicolumn{4}{|c|}{ Initial conditions } & \multicolumn{3}{|c|}{$\begin{array}{l}\text { Oil properties } \\
\text { (without } \mathrm{CO}_{2} \text { ) }\end{array}$} & \multicolumn{4}{|c|}{ Properties of oil saturated with $\mathrm{CO}_{2}$} \\
\hline & $\begin{array}{l}\text { Depth } \\
{[\mathrm{m}]}\end{array}$ & $\begin{array}{l}\text { Initial res. pres. } \\
\quad \text { [bar] }\end{array}$ & $\begin{array}{c}T_{R} \\
{\left[{ }^{\circ} \mathrm{C}\right]}\end{array}$ & $\begin{array}{l}\text { Satur. press } \\
\text { [bar] }\end{array}$ & $\begin{array}{c}R_{s} \\
{\left[\mathrm{~m}^{3} / \mathrm{m}^{3}\right]}\end{array}$ & $\left|\begin{array}{c}B_{o i} \\
{\left[\mathrm{~m}^{3} / \mathrm{m}^{3}\right]}\end{array}\right|$ & $\begin{array}{c}\mu_{\circ} \\
{[\mathrm{mPas}]}\end{array}$ & $\begin{array}{c}\text { Miscible } \\
\text { press. } \\
\text { [bar] }\end{array}$ & $\begin{array}{c}\mathrm{CO}_{2} \text { disolves } \\
\text { in oil } \\
{\left[\mathrm{m}^{3} / \mathrm{m}^{3}\right]}\end{array}$ & $\begin{array}{l}\text { Rock } \\
\text { volume } \\
\text { factor }\end{array}$ & $\begin{array}{l}\text { Viscosity } \\
\text { [mPas] }\end{array}$ \\
\hline Žutica & 1895 & 219 & 111 & 121 & 79 & 1.31 & 0.63 & 190 & 110 & 1.140 & 0.42 \\
\hline Ivanić & 1580 & 183 & 98 & 124 & 62 & 1.22 & 0.78 & 200 & 62 & 1.180 & 0.49 \\
\hline Obod & 2075 & 300 & 137 & 172 & 79 & 1.32 & 0.74 & 272 & 125 & 1.288 & 0.45 \\
\hline Števkovica & 2380 & 330 & 137 & 107 & 29 & 1.21 & 1.00 & 273 & 190 & 1.338 & 0.56 \\
\hline Beničanci & 1890 & 195 & 123 & 155 & 71 & 1.26 & 1.42 & 273 & 28 & 1.080 & 1.05 \\
\hline Šandrovac & 900 & 80 & 60 & 78 & 48 & 1.15 & 2.15 & 175 & 8.5 & 1.015 & 0.52 \\
\hline Lepavina & 600 & 59 & 66 & & & & 15.30 & & 48 & 1.093 & 7.50 \\
\hline
\end{tabular}

$T_{R}$ - reservoir temperature, $R_{s}$ - gas/oil ratio, $B_{o i}$ - oil formation volume factor, $\mu_{\mathrm{o}}$ - dynamic viscosity

$\mathrm{CO}_{2}$ and an alternation of $\mathrm{CO}_{2}$ and water injection (water alternate gas, WAG) under initial conditions. The second simulation curve (case $\mathrm{B}$ ) is the result of a continuous injection of $\mathrm{CO}_{2}$ or WAG into a partially or completely water-flooded reservoir. The third simulation curve (case $\mathrm{C}$ ) refers to a continuous foam injection or an alternate foam and water injection (water alternate foam - WAF). The simulation model was based on one reservoir from the Gamma "series" with two injection well lines and producing wells in the middle (Perić and Kovač, 2003).

Results singled out the Ivanić oil field as one of the most suitable for the EOR method in the reservoir, with porosity $21.5-23.6 \%$, permeability $14-80 \times 10^{-15} \mathrm{~m}^{2}$, and initial water saturation of 28-38.5\% (Perić and Kovač, 2003; Malvić, 2008). EOR would result in solubility of $\mathrm{CO}_{2}$, and consequently an oil swelling increase of $17 \%$, viscosity reduction by $30 \%$ (Fig. 2), and volume expansion. Calculations included $\mathrm{CO}_{2}$-oil minimum miscible pressures, efficiency of oil displacement using $\mathrm{CO}_{2}$ at varying reservoir pressure, temperature, and fluid saturations. Total oil recovery would be increased using alternating injections of WAG.

\section{DATA AND METHODS}

Data sources used for this research can be divided into three groups:

- Kloštar Field data used for review of Neogene geological evolution for one typical structure in the Sava Depression, where injection and carbonation of $\mathrm{CO}_{2}$ in the reservoir rocks could be applied;

- mineralogical data averaged for Upper Miocene sandstones in the Sava Depression, which would target mature or depleted hydrocarbon reservoirs for $\mathrm{CO}_{2}$ injection;

- reservoir maps and volume calculations of Upper Miocene reservoirs predicted injection of $\mathrm{CO}_{2}$ in the Sava Depression. Gamma 3 and Gamma 4 were shown for the Ivanić Field (i.e., Upper Pannonian sandstone reservoirs), whereby geological evolution and reservoir properties could be easily correlated and compared for the adjacent Kloštar and Ivanić fields.

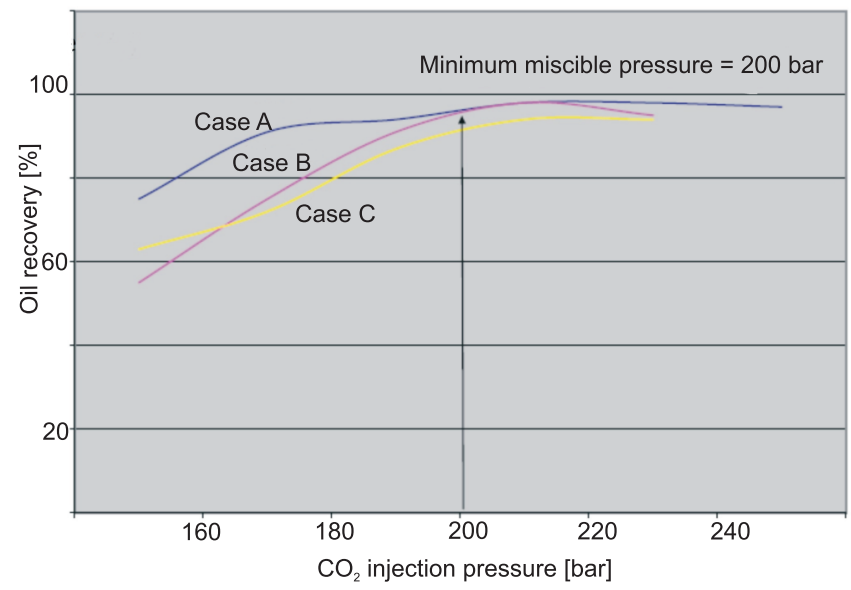

Fig. 1. Minimal miscible pressure for $\mathrm{CO}_{2}$ (from Goričnik and Domitrović, 2003; Novosel, 2009)

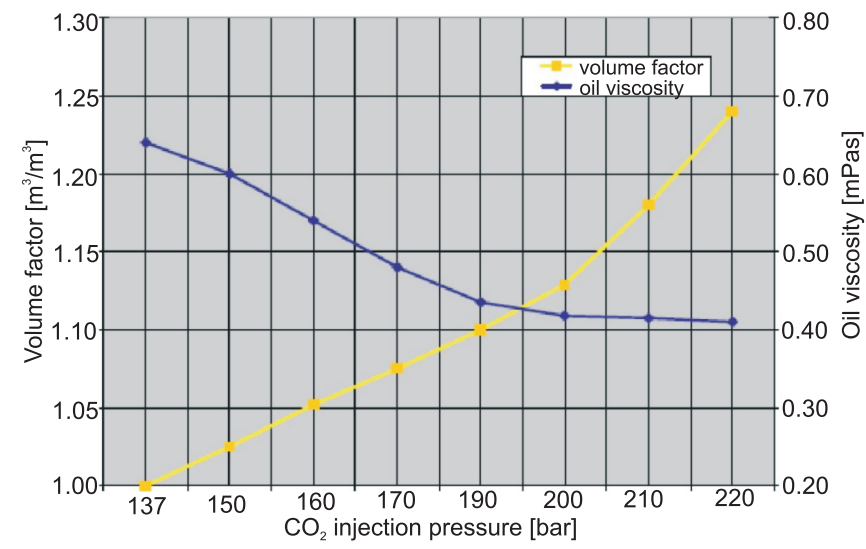

Fig. 2. Viscosity changes and volume increase of oil saturated with $\mathrm{CO}_{2}$ (from Goričnik and Domitrović, 2003; Novosel, 2009) 
The applied interpretation methods included part of the palinspastic reconstruction for the Kloštar Field as well as mapping of the reservoirs in the Ivanić Field using Kriging. The typical lithological and lithostratigraphical section, with sandstone members as targets for $\mathrm{CO}_{2}$ injection and carbonization, are given for the case of the close Ivanić Field. The volume of $\mathrm{CO}_{2}$ that would be bounded in the carbonization process in such reservoirs is assumed from the total possible amount of injected $\mathrm{CO}_{2}$. The $\mathrm{CO}_{2}$ amount is estimated through analogy with a geochemical model described by Wilkinson et al. (2009), and using a mineralogical model of Upper Miocene sandstones in the Sava Depression.

\section{GEOLOGICAL SETTINGS AND MINERAL COMPOSITION OF THE UPPER MIOCENE SANDSTONES OIL RESERVOIRS IN THE SAVA DEPRESSION}

The Sava Depression is located about $40 \mathrm{~km}$ south-east of Zagreb (Fig. 3) and consists of numerous fields where hydrocarbons accumulated in Upper Miocene sandstone lithostratigraphic members. The distribution and geometry of sandstone bodies were strongly influenced by the depositional palaeoenvironment and deposition from turbidites in lacustrine, mostly brackish environments (Malvić, 2012). The entire chrono- stratigraphy and lithostratigraphy is valid for the entire Croatian part of the Pannonian Basin System shown in Figure 4. The most important hydrocarbon reservoirs in the Ivanić Field, as the planned targets for $\mathrm{CO}_{2}$ injection, are within the Upper Pannonian substage. They are informally (in the rank of bed) called the "Gamma series" reservoirs. There are about seven particular sandstone bodies created as single depositional events, deposited during the Upper Pannonian in lacustrine environments with consequent activity of turbiditic currents. Lithologically, they are fine-grained (mineralogically dominantly quartz and mica) sandstones alternating with marls and calcitic marls described by Velić et al. (2011), Malvić (2012), Novak Zelenika (2012), and Novak Zelenika et al. (2013).

The depositional model during the Upper Miocene, Pliocene, Pleistocene, and Holocene can be clearly followed onto sketches derived from Novak Zelenika (2012). Such conceptual models (Figs. 5-8) were reconstructed based on data mostly obtained from structural maps and palaeotectonic profiles published by Velić et al. (2011) for the adjacent Kloštar Field. However, the Ivanić and Kloštar fields share almost the same depositional history, lithology, lithostratigraphy (only the particular reservoirs have different informal names), and structural development. Thanks to comprehensive analyses given by Velić et al. (2011), it was easy to correlate and extend results and conclusions onto the Ivanić Structure. According to Malvić and Velić (2011) and Malvić (2012), a 2nd transtension prevailed during Upper Pannonian and Lower Pontian in the western part

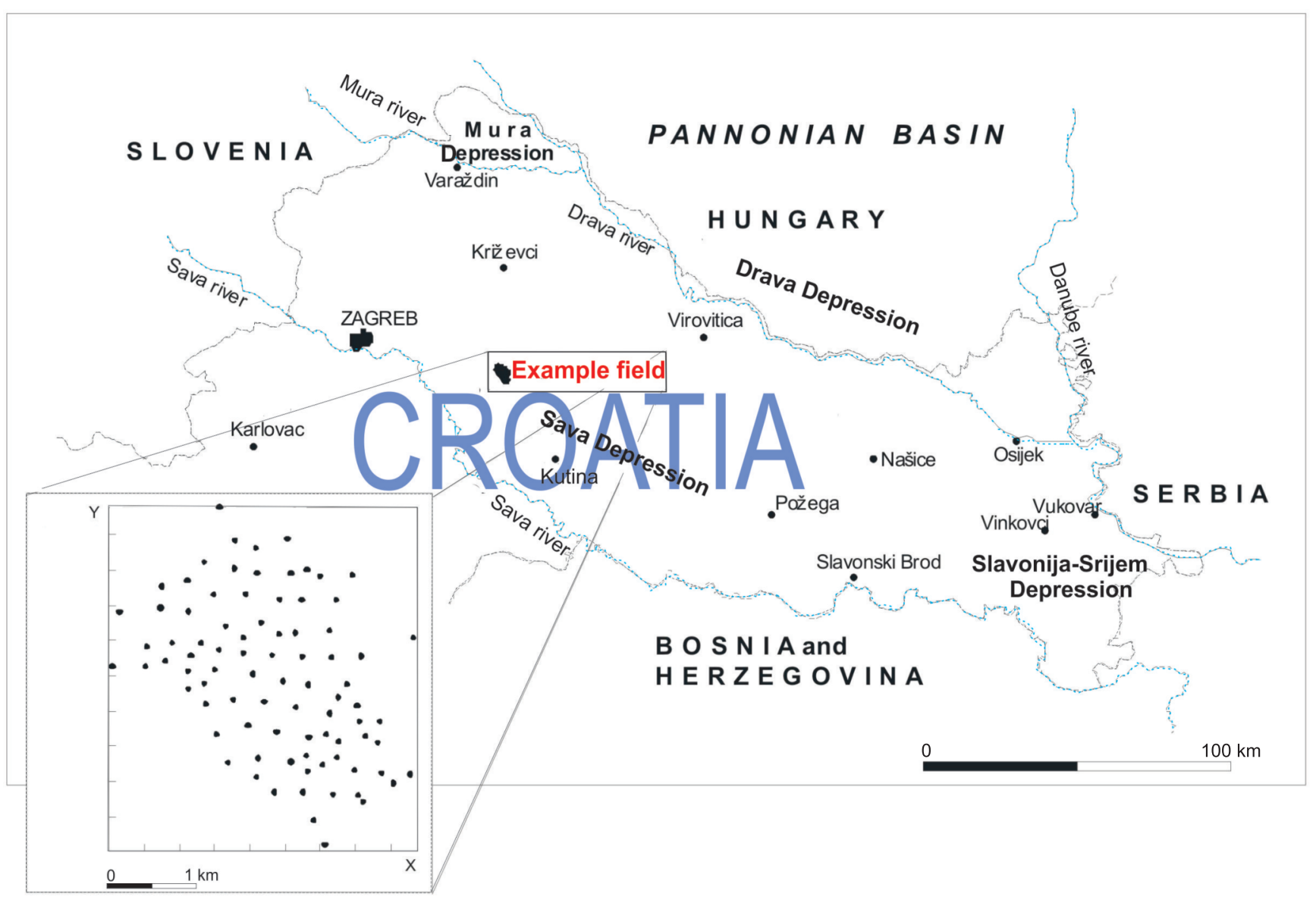

Fig. 3. The schematic map of the Ivanić Field location in the Croatian part of the Pannonian Basin System and outlined the most of western part (from Novak et al., 2013) 


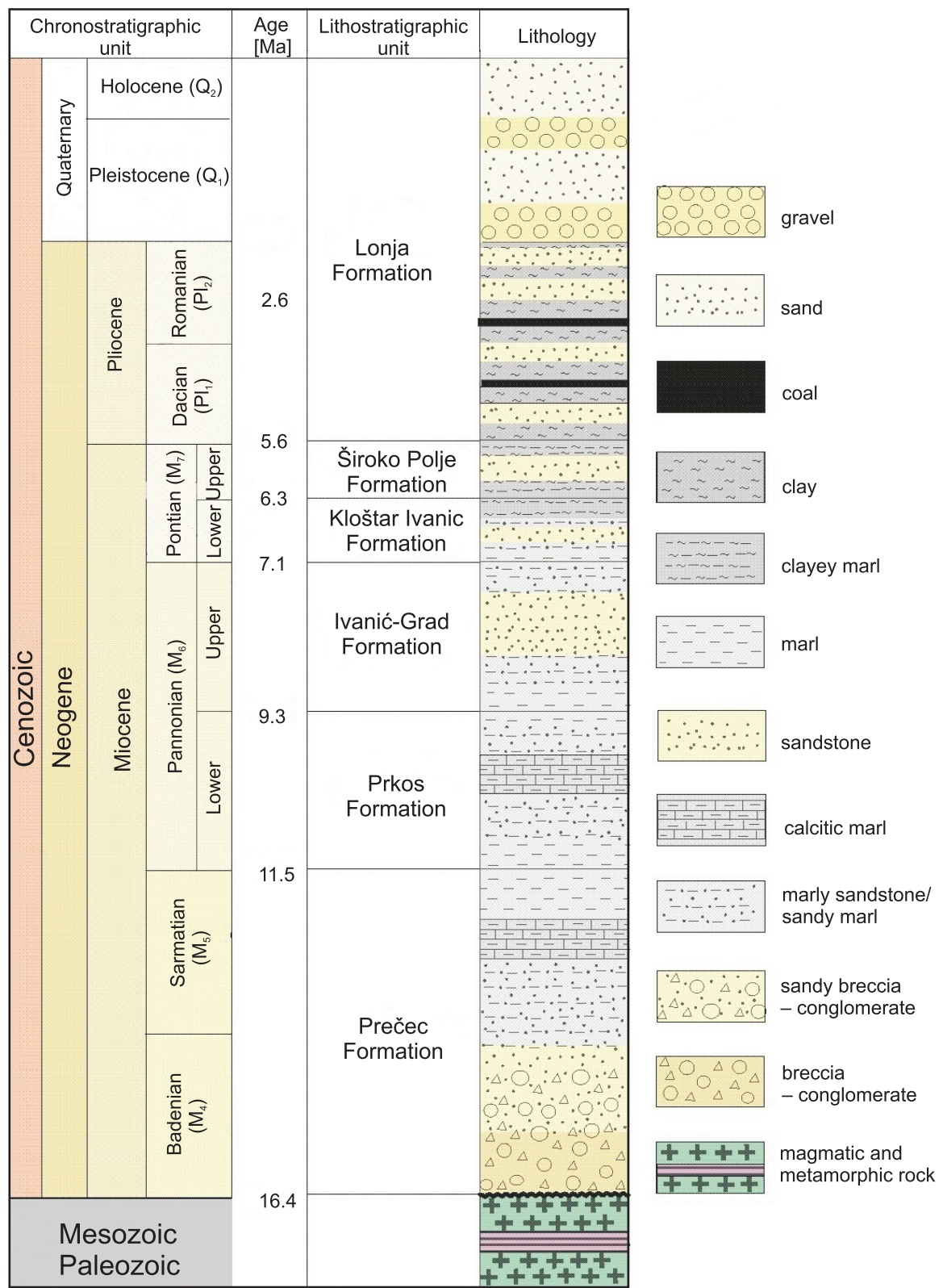

Fig. 4. Lithostratigraphic and chronostratigraphic units, ages and lithologies in the Ivanić Field

of Sava Depression as well as in the whole area of the Croatian part of the Pannonian Basin System (Figs. 5 and 6). At the transition from the Upper Pannonian to the Lower Pontian, the large normal fault appeared, which caused uplifting of the NE part (Fig. 6) and an uplifting feature along the entire southwestern margin of the palaeo Moslavačka gora Mt. All macrostructures located along that margin in the deeper part of the lacustrine basin today called the Sava Depression were influenced.

The main fault created the deeper environment in the Lower Pontian Sava Lake and probably opens the possibility of considering two active sources of material in that time. The first and main were the Eastern Alps, a mineralogically and palaeotectonically proven dominant clastic source that fed numerous and consequent turbidite currents in the Upper Miocene (e.g., Vrbanac et al., 2010). However, with a faulted and steep margin of uplifted palaeorelief along the margin of the Sava Depression, the Moslavačka gora Mt. is a typical example of such macrostructure where areas could be characterized with locally eroded material, and transported through small alluvial fans. During the Late Pontian 2nd transpression (Malvić and Velić, 2011; Malvić, 2012), which is active still today (Figs. 7 and 8), the western Sava Depression formed and has been gradually filled with deposits (Fig. 7) and changed into real continental environments (Fig. 8) with sporadically small alluviums. The character of the dominantly large normal faults was changed into reversal character, and only smaller ones in the top remained with small normal displacement. The period of the 2 nd transpression is also a period when anticlines along the northwestern margins of the Sava Depression were formed, similarly to the evolution of the Kloštar Structure (sketched in Figs. 7 and 8). 


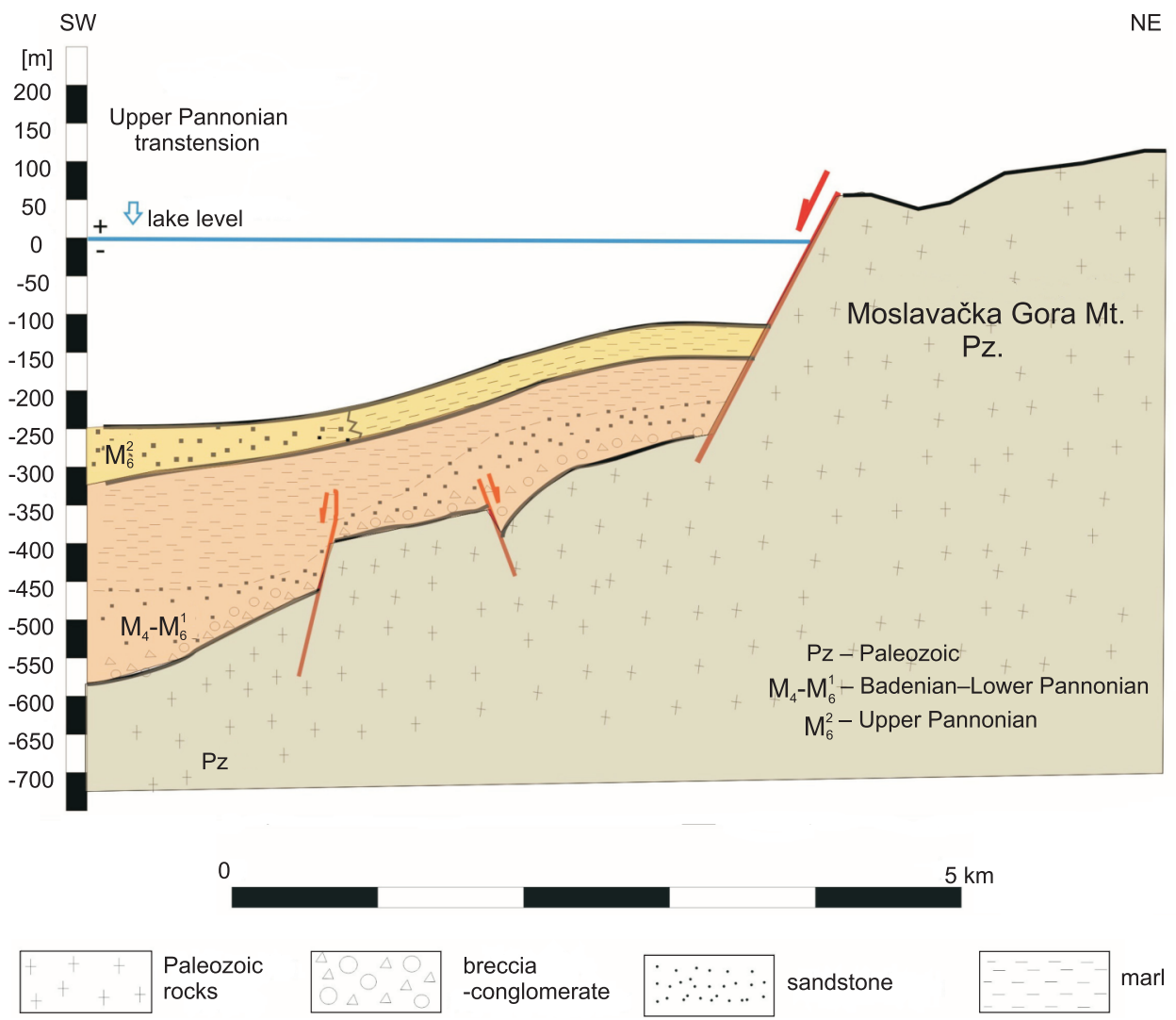

Fig. 5. Evolution of the Kloštar Structure along southwestern margin of the Moslavačka gora Mt. in Upper Pannonian (Novak Zelenika, 2012)

\section{$\mathrm{CO}_{2}$-REACTIVE MINERALS IN THE UPPER MIOCENE SANDSTONES OF THE SAVA DEPRESSION}

Previous studies showed that alkaline earth metals, calcium and magnesium, are the most suitable for mineral carbonation. Various natural and synthetic materials (minerals), listed in Table 5, were investigated in Sipilä et al. (2008). However, for mineral carbonation the use of magnesium-based silicates, $\mathrm{xMgO}$ $\times \mathrm{ySiO}_{2} \times \mathrm{zH}_{2} \mathrm{O}$, is favoured because they are available in large amounts worldwide (Zevenhoven and Kohlmann, 2002). The most abundant such silicates are olivine, $(\mathrm{Mg}, \mathrm{Fe}) \mathrm{SiO}_{4}$, and serpentine, $\mathrm{Mg}_{3} \mathrm{Si}_{2} \mathrm{O}_{5}(\mathrm{OH})_{4}$, which are both marked in Table 7. The chemistry of $\mathrm{CO}_{2}$ binding (with extending Equation 1) can be summarized as (Equations 2 and 3 ):

$$
\begin{gathered}
\mathrm{aMgO} \times \mathrm{bSiO}_{2} \times \mathrm{cH}_{2} \mathrm{O}(\mathrm{s})=>\mathrm{aMgO}(\mathrm{s})+ \\
+\mathrm{bSiO}_{2}(\mathrm{~s})+\mathrm{CH}_{2} \mathrm{O}(1 \text { st reaction) } \\
\mathrm{MgO}+\mathrm{CO}_{2}=>\mathrm{MgCO}_{3} \text { (2nd reaction) }
\end{gathered}
$$

Both reactions are exothermal, releasing $64 \mathrm{~kJ} / \mathrm{mol}$ in serpentinite rock or $90 \mathrm{~kJ} / \mathrm{mol}$ for pure olivine or forsterite minerals. According to Zevenhoven et al. (2012), mass flows of fuel and carbonated mineral for a typical power plant will be of the same order of magnitude. For example, $1 \mathrm{~kg}$ of $\mathrm{CO}_{2}$ may require $2 \mathrm{~kg}$ of serpentine and result in about $30 \mathrm{wt} . \%$ bound $\mathrm{MgO}$ for disposal.

The Upper Miocene sandstone reservoirs in the Sava Depression are fine- to medium-grained, with particle dimensions between 30 and $500 \mu \mathrm{m}$. The sandstones are mostly wellsorted with no major compositional variations, like marls or claystone intercalations. Mineralogically, the sandstones are relatively uniform, and sporadically in transitional lithofacies that include various amounts of carbonate cements and clays. Mostly pure sandstones consist predominantly of quartz and dolomite rock fragments with less abundant micas, altered feldspars, chlorite, cherts, quartzite, and mica-schist rock fragments. Typical major components of sandstones (Tadej et al., 1996) are $\mathrm{SiO}_{2}$, i.e. quartz (40-50\%), $\mathrm{CaMg}\left(\mathrm{CO}_{3}\right)_{2}$, i.e. dolomite rock fragments $(15-25 \%), \mathrm{K} / \mathrm{Na}-\mathrm{Al}_{2}(\mathrm{OH})_{2} \mathrm{AlSi}_{3} \mathrm{O}_{10}$ micas (10-15\%), $\mathrm{KAISi}_{3} \mathrm{O}_{8} \mathrm{~K}$-feldspars (5-10\%), and cement (5-20\%). Pore sizes in the sandstones are about 10-15 $\mu \mathrm{m}$, and rarely up to $100 \mu \mathrm{m}$. The matrix is typically composed of carbonate-silicate cement (made of dolomite, calcite, sericite and quartz) with $5 \mu \mathrm{m}$-sized crystals and sometimes clays particles.

Table 6 shows the dominant mineral compositions of Upper Miocene sandstones in the Sava Depression. Generally, the 


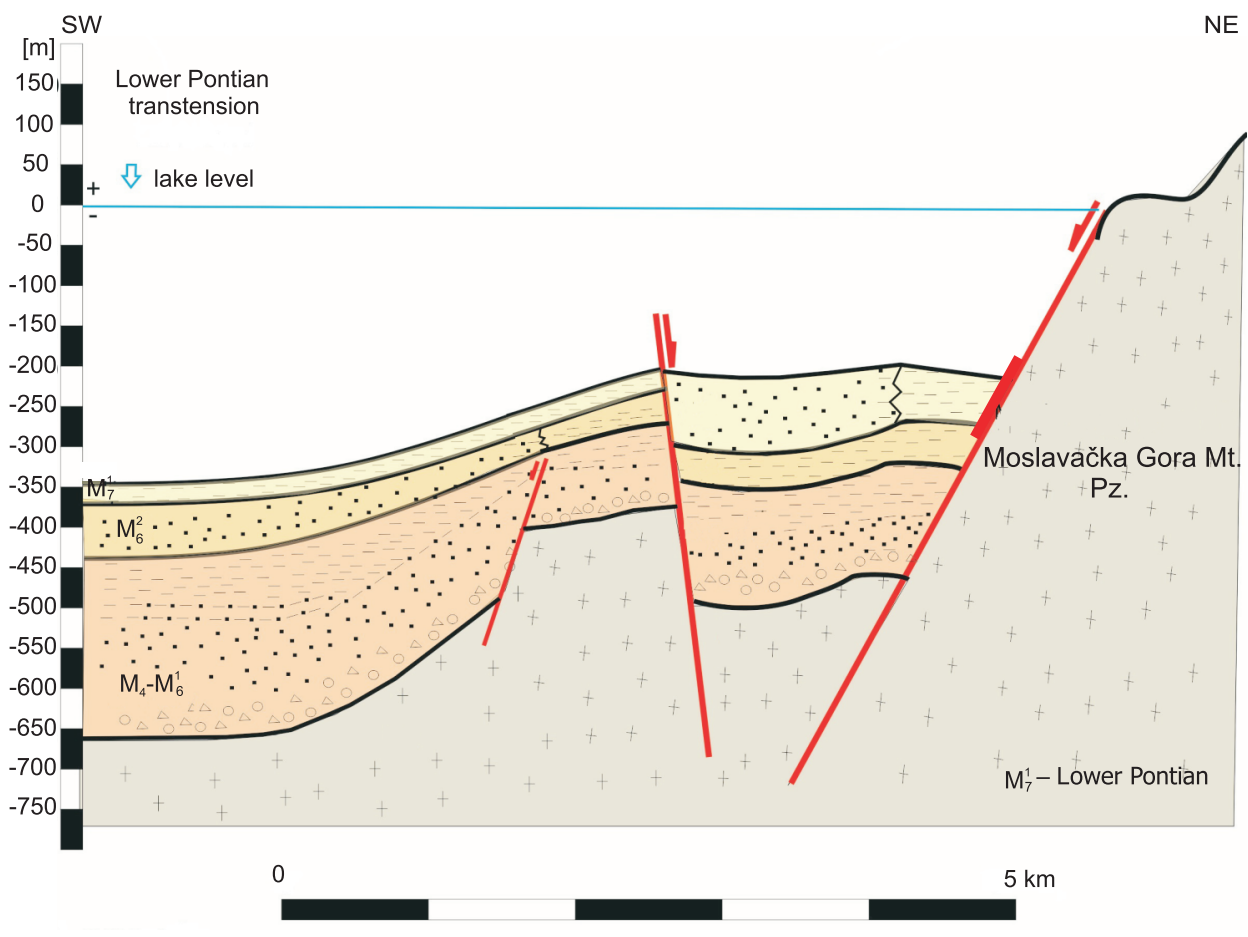

Fig. 6. Evolution of the Kloštar Structure along southwestern margin of the Moslavačka gora Mt. in Lower Pontian (Novak Zelenika, 2012)

For explanations see Figure 5

sandstones do not have large binding capacities for $\mathrm{CO}_{2}$ due to lack of: alkaline earth metals (Ca and $\mathrm{Mg}$ ) in forms of natural silicate minerals (such as olivine, serpentine, and wollastonite) and/or basalt rock fragments inside.

$\mathrm{CO}_{2}$ in sandstones will induce aluminosilicate dissolution and carbonate cementation if silicate minerals contain $\mathrm{Ca}, \mathrm{Mg}$, or Fe. However, in any case, it is not observable on a human timescale. Baines and Worden (2004) stated that even porous sandstones filled with large volumes of $\mathrm{CO}_{2}$ some $8,000-100,000$ years ago and characterized with abundant reactive aluminosilicate minerals, show only minimal evidence of solid phase sequestration.

\section{CALCULATION OF VOLUME AVAILABLE FOR $\mathrm{CO}_{2}$ TOTAL STORAGE AND MINERAL TRANSFORMATION (CASE STUDY SAVA DEPRESSION, IVANIĆ FIELD)}

The gross volume could be calculated based on the maps of porosity and thickness for both analysed mature reservoirs planned for $\mathrm{CO}_{2}$ injection into the Ivanić Field. Both reservoirs are of Upper Pannonian age, with younger Gamma 3 (Figs. 9 and 10) and older Gamma 4 (Figs. 11 and 12).

Using those maps and water saturation data $(26.4 \%$ in Gamma 3, 26.1\% in Gamma 4), the total porosity rock volume was calculated (Table 7 ).

Volumes of injected $\mathrm{CO}_{2}$ (dissolved in water and oil) could be calculated according to the equation of state for real gases [4]. Corresponding mass are given in Table 8.

$$
p_{R} \times V_{p T}=z \times \frac{m_{\mathrm{CO}_{2}}}{M_{\mathrm{CO}_{2}}} \times R \times T_{R}
$$

where: $p_{R}$ - reservoir pressure $(\mathrm{Pa}), V_{p T}$ - volume at defined pressure and temperature, $R$-ideal gas constant $[8.314 \mathrm{~J} /(\mathrm{mol} \mathrm{K})], z-$ compressibility factor (for used values $98^{\circ} \mathrm{C}, 200 \times 105 \mathrm{~Pa}$ it was $0.6), m_{\mathrm{CO}_{2}}-$ mass $\mathrm{CO}_{2}(\mathrm{~kg}), M_{\mathrm{CO}_{2}}-$ molar mass $\mathrm{CO}_{2}(\mathrm{~kg} / \mathrm{mol}), T_{R}-$ reservoir temperature $\left[\mathrm{C}^{\circ}\right]$.

The Sava Depression is composed of $45 \%$ quartz, $20 \%$ dolomite, $10 \%$ mica $\left[\mathrm{KAl}_{2}(\mathrm{OH})_{2} \mathrm{AlSi}_{3} \mathrm{O}_{10}\right], 10 \%$ K-feldspar $\left(\mathrm{KAISi}_{3} \mathrm{O}_{8}\right)$ with grain size $150 \mathrm{~mm}$ and $15 \%$ cement (dolomite, calcite, sericite, quartz) of $5 \mathrm{ppm}$, averaged from Table 6 . All sandstone reactions are kinetically assumed (Caroll et al., 2011) with Equation 5:

$$
r \pm k A\left(1-\frac{I A P}{K_{s p}}\right)
$$

where: $r$-dissolution or precipitation rate per unit time per unit area, $k$ - kinetic rate constant, $A$ - mineral surface area, IAP - ion activity product, $K_{s p}-$ solubility constant.

Carroll et al. (2011) showed in a model that all reactive available surfaces in sandstone are assumed to be active. Also, dolomite is the source for $\mathrm{Ca}^{2+}$ and $\mathrm{Mg}^{2-}$, and part of micas (e.g., illite) of $\mathrm{Si}^{4+}$. However, feldspars are generally thought to be the most abundant source of cations for forming $\mathrm{CO}_{2}$ sequestering minerals, although many natural $\mathrm{CO}_{2}$ fields did not completely react, and carbonate formation was highly 


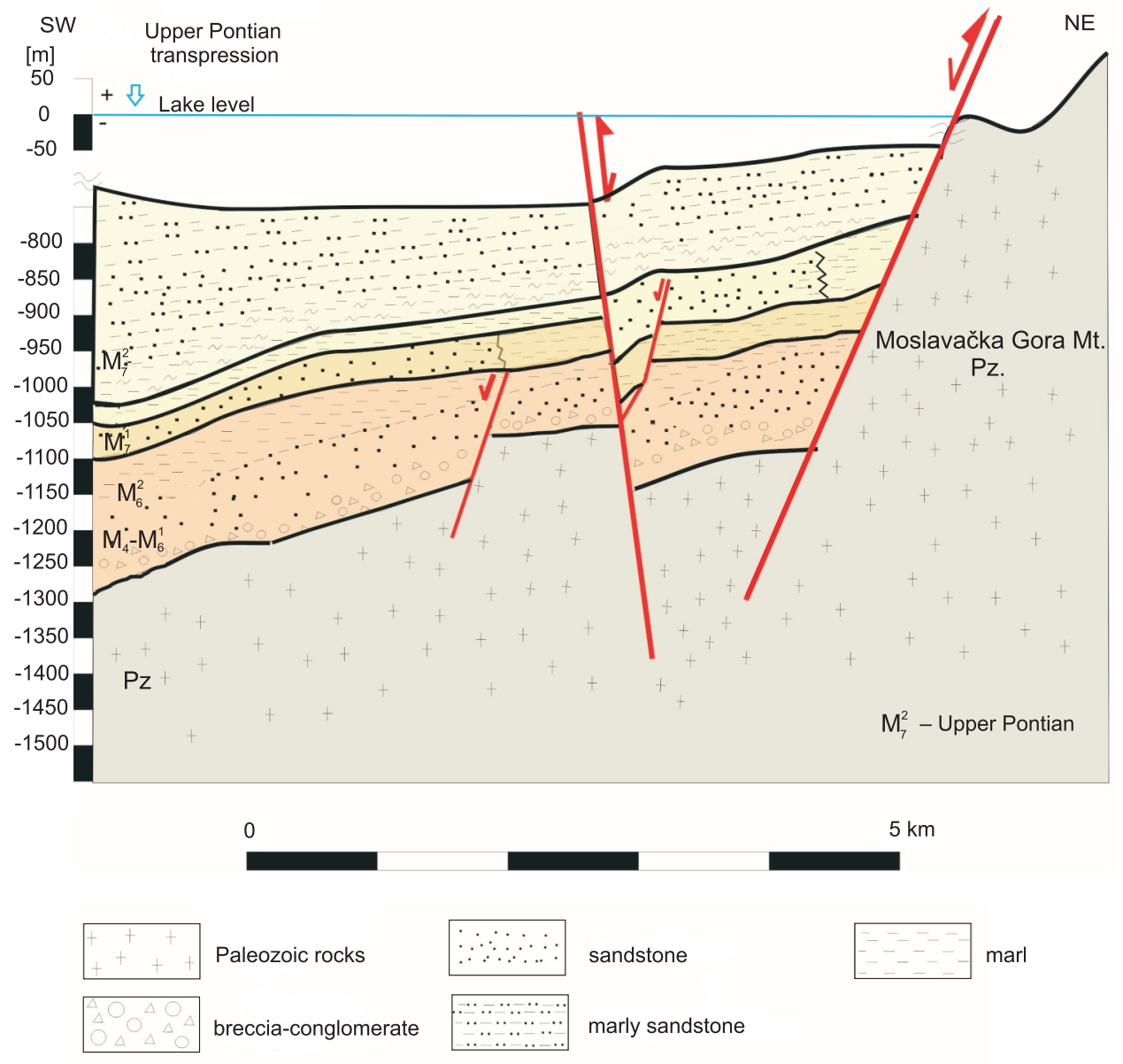

Fig. 7. Evolution of the Kloštar Structure along southwestern margin of the Moslavačka gora Mt. in Upper Pontian (Novak Zelenika, 2012)

For explanations see Figure 5

sensitive to prevailing conditions. Except in the Werkendam, the Dutch natural analogue for $\mathrm{CO}_{2}$ storage sequestered in siderite and dolomite is small (Koenen et al., 2013). Feldspars comprised approximately $10 \%$ of analysed rocks, and dolomite approximately $20 \%$, which makes them potentially favourable sandstones for sequestration. The gross volume of sandstone reservoir Gamma 3 was approximately 107 million $\mathrm{m}^{3}$ and Gamma 4 was approximately 62 million $\mathrm{m}^{3}$, shown in Table 7 . Multiplying by average density $\left(2500 \mathrm{~kg} / \mathrm{m}^{3}\right)$ results in masses of approximately 268 and approximately 155 million t, respectively.

\section{DISCUSSION ON UNCERTAINTIES}

$\mathrm{CO}_{2}$ sequestration by mineral carbonation is environmentally benign because it permanently traps $\mathrm{CO}_{2}$ in the form of carbonated minerals. Unlike other $\mathrm{CO}_{2}$ sequestration routes, it provides a leakage-free sequestration without a need for poststorage surveillance and monitoring, once the $\mathrm{CO}_{2}$ is bound into carbonates. Those are also exothermic processes. Extrapolation of some previous ex situ studies to in situ mineral sequestration led to promising results for some localities that can reach $1.4-5.4 \times 10^{-9} \mathrm{molCO}_{2} / \mathrm{cm}^{2}$. day in serpentinite rock. Elements like alkaline earth metals, calcium and magnesium, were proven as the most suitable for carbonation because of their abundance and insolubility. Olivine and wollastonite are the most favourable minerals, while ultramafic rocks, particularly serpentinite, have proven to be suitable for the process. It is clear that sandstone lithologies are not a favourable rock medium for mineral storage of $\mathrm{CO}_{2}$, mostly because dissolution of reactive aluminosilicate or precipitation of carbonate minerals are slow processes on human time scales.

However, in some cases such as for dawsonite, $\mathrm{NaAlCO}_{3}(\mathrm{OH})_{2}$ (Liu et al., 2011), the mineral sequestration in sandstones can be a very efficient process. For example, Yu et al. (2014) reported mineral sequestration in Upper Miocene sandstone reservoirs at $94-97^{\circ} \mathrm{C}$ in the Songliao Basin, China which is very close to the temperature of $\mathrm{CO}_{2}$ planned for injection in Croatia.

Also, cement carbonation is the dominant geochemical alteration process in a near-well, or infiltrated zone of deep boreholes. It can mask reactivity of sandstone minerals, which can be a problem with indirect, or in well, measurements. The cement can increase the amount of dissolved $\mathrm{Ca}^{2+}$, which increases $\mathrm{Si}^{4+}$ and can result in smectite precipitation both in rock and cement.

Considering such mechanism of $\mathrm{CO}_{2}$ storage in Northern Croatia, particularly the Sava Depression, it is still in experimental stage and theoretical observation. Future research must determine how such a process can increase the total volume of stored $\mathrm{CO}_{2}$ by two other mechanisms (dissolving in brine and forming gas cap). 


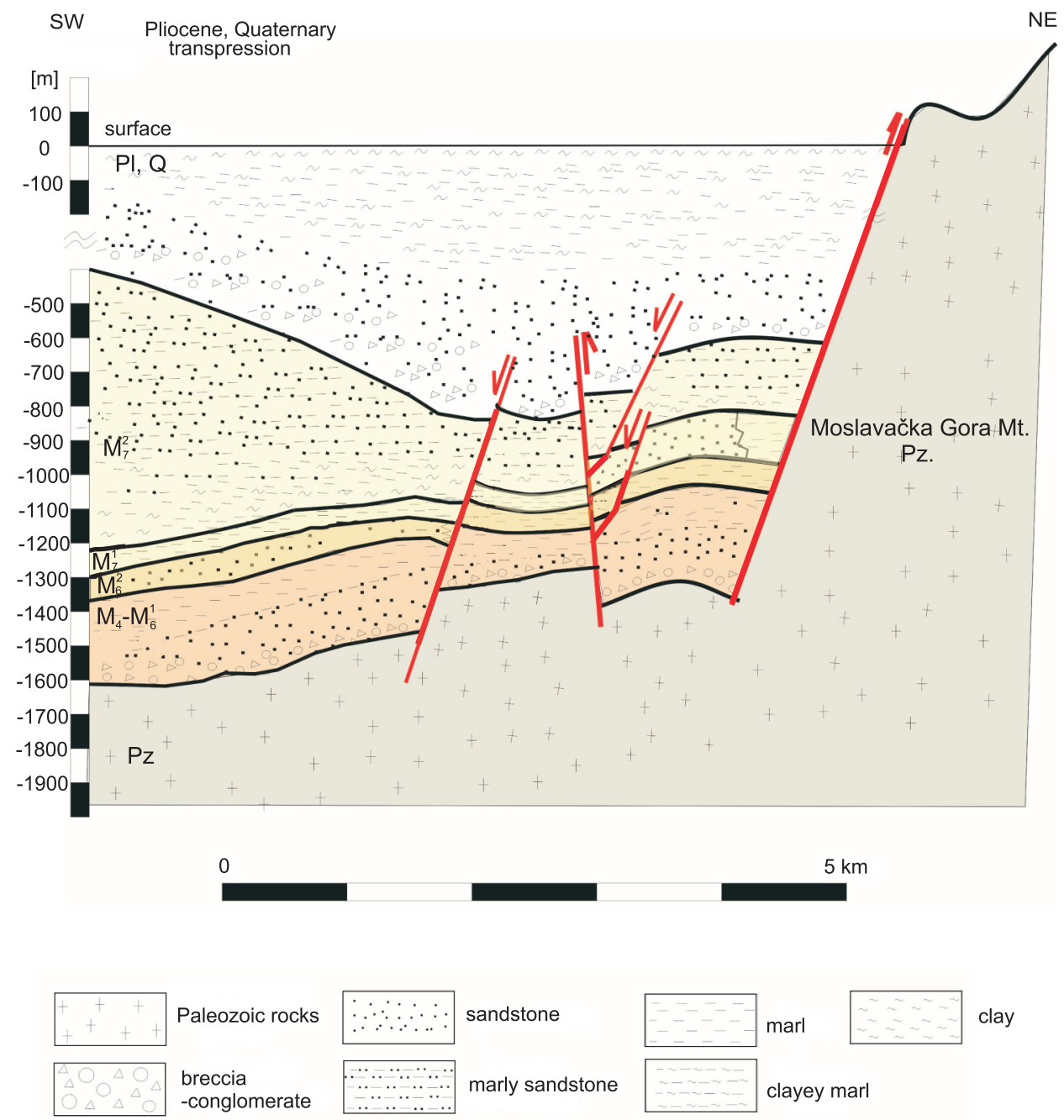

Fig. 8. Evolution of the Kloštar Structure along southwestern margin of the Moslavačka gora Mt. in Pliocene and Quaternary (Novak Zelenika, 2012)

For explanations see Figures 4 and 5

Mineral types and synthetic minerals investigated for carbonation in research papers and reports (2005-2007) (Sipilä et al., 2008)

\begin{tabular}{|c|c|c|c|}
\hline MINERAL & FORMULA/COMPOSITION & SYNTHETIC MATERIAL & FORMULA/COMPOSITION \\
\hline Feldspar & $\mathrm{CaAl}_{2} \mathrm{Si}_{2} \mathrm{O}_{8}$ & calcium silicate & $\mathrm{CaSiO}_{3}, \mathrm{Ca}_{2} \mathrm{SiO}_{4}$ \\
\hline Forsterite & $\mathrm{Mg}_{2} \mathrm{SiO}_{4}$ & caustic lime & $\mathrm{CaO}$ \\
\hline Glauconite & $\begin{array}{c}(\mathrm{K}, \mathrm{Na}, \mathrm{Ca})_{1.2-2}\left(\mathrm{Fe}^{3+}, \mathrm{Al} \mathrm{Fe}^{2+}, \mathrm{Mg}\right)_{4} \mathrm{x} \\
\left(\mathrm{Si}_{7-7.6} \mathrm{Al}_{1-1.4} \mathrm{O}_{20}\right)(\mathrm{OH})_{4} \mathrm{nH}_{2} \mathrm{O}\end{array}$ & enstatite & $\mathrm{MgSiO}_{3}$ \\
\hline IImenite & $\mathrm{FeTiO}_{3}$ & forsterite & $\mathrm{Mg}_{2} \mathrm{SiO}_{4}$ \\
\hline Listwanite & carbonated serpentinite & hydromagnesite & $\left(\mathrm{MgCO}_{3}\right)_{4} \cdot \mathrm{Mg}(\mathrm{OH})_{2} \cdot 4 \mathrm{H}_{2} \mathrm{O}$ \\
\hline Magnetite & $\mathrm{Fe}_{3} \mathrm{O}_{4}$ & limestone & $\mathrm{CaCO}_{3}$ \\
\hline Olivine & $(\mathrm{Mg}, \mathrm{Fe})_{2} \mathrm{SiO}_{4}$ & magnesia & $\mathrm{MgO}$ \\
\hline Opoka & mainly $\mathrm{CaCO}_{3}, \mathrm{SiO}_{2}$, hematite and muscovite & magnesite & $\mathrm{MgCO}_{3}$ \\
\hline Pyroxene & $\mathrm{CaMgSi}_{2} \mathrm{O}_{6}+(\mathrm{Fe}, \mathrm{Al})$ & merwinite & $\mathrm{Ca}_{3} \mathrm{Mg}\left(\mathrm{SiO}_{4}\right)_{2}$ \\
\hline Serpentine & $\mathrm{Mg}_{3} \mathrm{Si}_{4} \mathrm{O}_{10}(\mathrm{OH})_{2}$ & nesquehonite & $\mathrm{MgCO}_{3} \cdot 3 \mathrm{H}_{2} \mathrm{O}$ \\
\hline Talc & $\mathrm{Mg}_{3} \mathrm{Si}_{4} \mathrm{O}_{10}(\mathrm{OH})_{2}$ & slaked lime & $\begin{array}{c}\mathrm{Ca}(\mathrm{OH})_{2} \\
(\mathrm{Ca}, \mathrm{Na})_{2}(\mathrm{Mg}, \mathrm{Al})(\mathrm{Si}, \mathrm{Al})_{3} \mathrm{O}_{7}\end{array}$ \\
\hline Wollastonite & $\mathrm{CaSiO}_{3}$ & & \\
\hline
\end{tabular}


Typical major components of sandstones in the Sava Depression (data from Tadej et al., 1996)

\begin{tabular}{|l|c|c|c|}
\hline \multicolumn{1}{|c|}{ Mineral composition } & Formula & Grain size $[\mu \mathrm{m}]$ \\
\hline Quartz & $\mathrm{SiO}_{2}$ & $40-50$ & \multirow{2}{*}{$30-500$} \\
\cline { 1 - 2 } Dolomite & $\left.\mathrm{CaMg}_{2} \mathrm{CO}_{3}\right)_{2}$ & $15-25$ & \\
\cline { 1 - 2 } Micas & $\mathrm{KAl}_{2}(\mathrm{OH})_{2} \mathrm{AlSi}_{3} \mathrm{O}_{10}$ & $10-15$ & \\
\cline { 2 - 3 } & $\mathrm{NaAl}_{2}(\mathrm{OH})_{2} \mathrm{AlSi}_{3} \mathrm{O}_{10}$ & & \\
\hline K-feldspars & $\mathrm{KAISi}_{3} \mathrm{O}_{8}$ & $5-10$ & \\
\hline
\end{tabular}

Table 7

Volumes in reservoirs Gamma 3 and 4

\begin{tabular}{|l|c|c|}
\hline \multicolumn{1}{|c|}{ Calculated volumes $\left[\mathrm{m}^{3}\right]$} & Gama 3 & Gama 4 \\
\hline Volume of total reservoir rocks & $107,224,438$ & $62,132,698$ \\
\hline Volume of porosity above oil-water contact & $20,223,642$ & $5,524,923$ \\
\hline Volume of porosity below oil-water contact & $1,531,357$ & 42,984 \\
\hline Volume of oil saturated part above contact & $14,884,600$ & $4,082,918$ \\
\hline Volume of water saturated part above contact & $5,339,041$ & $1,442,005$ \\
\hline
\end{tabular}

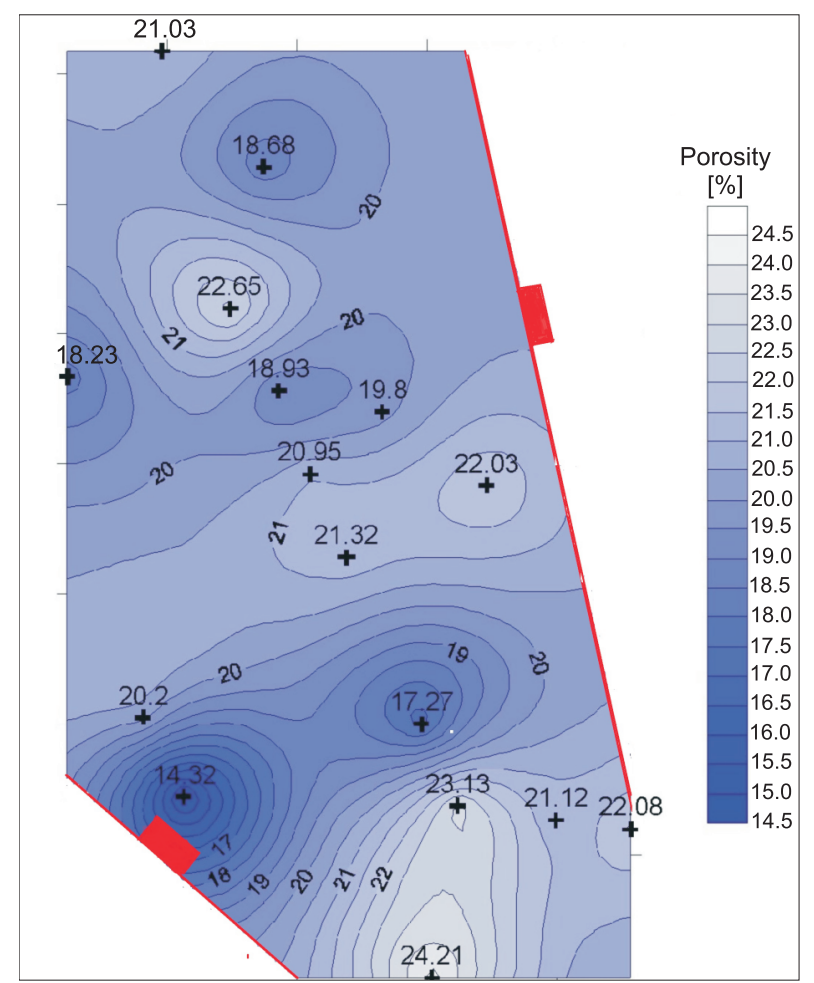

Fig. 9. The porosity Ordinary Kriging map, reservoir Gamma 3, Ivanić Field

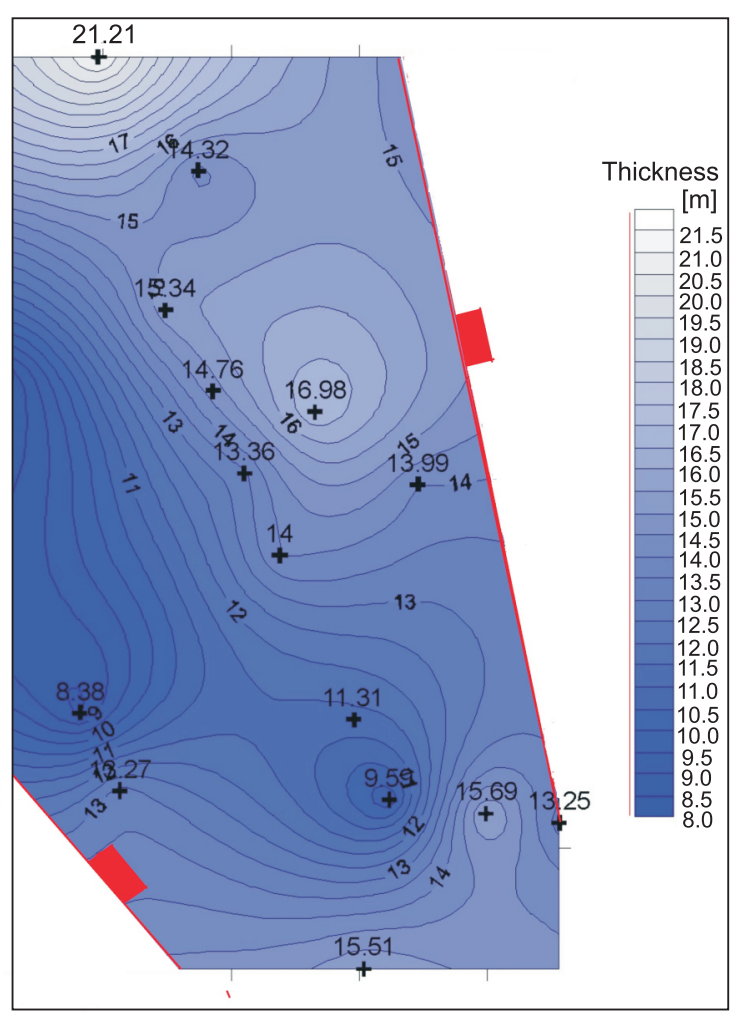

Fig. 10. The thickness Ordinary Kriging map, reservoir Gamma 3, Ivanić Field 


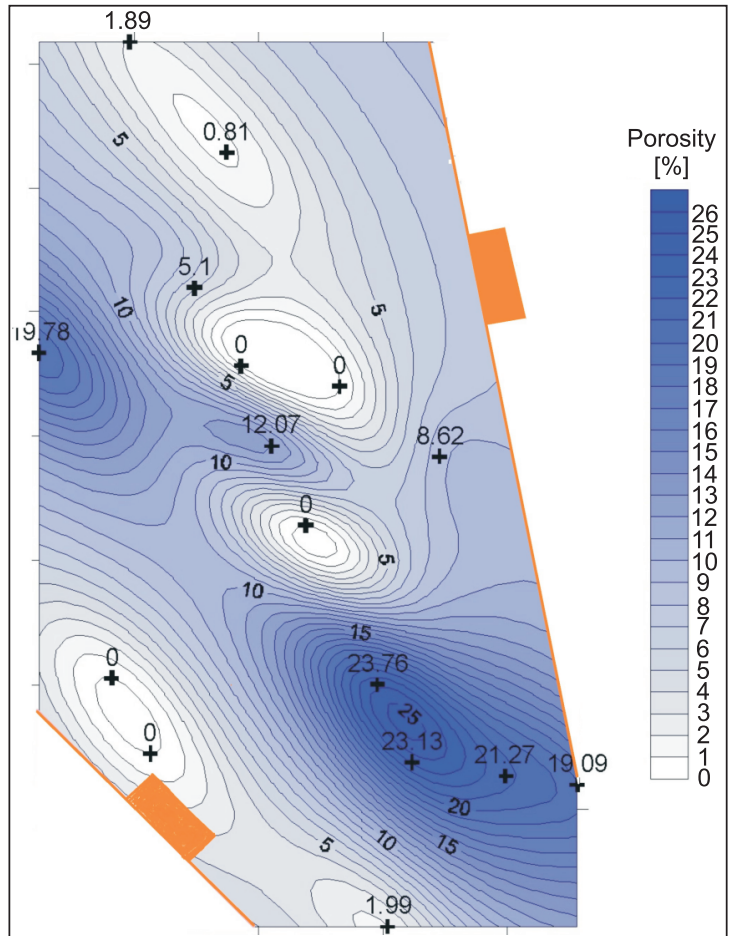

Fig. 11. The porosity Ordinary Kriging map, reservoir Gamma 4, Ivanić Field

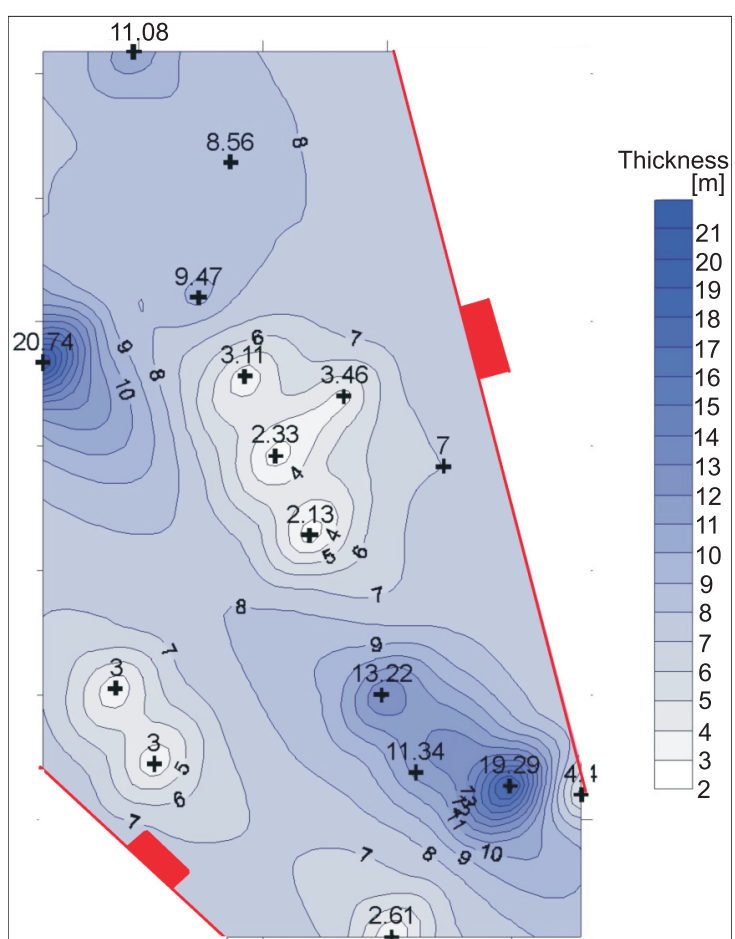

Fig. 12. The thickness Ordinary Kriging map, reservoir Gamma 4, Ivanić Field
Table 8

Mass of $\mathrm{CO}_{2}$ that could be injected in reservoirs Gamma 3 and 4

\begin{tabular}{|l|c|c|}
\hline $\begin{array}{c}\text { Mass of } \mathrm{CO}_{2} \text { (tonnes, } 200 \text { bars, } 98^{\circ} \mathrm{C} \text { ) } \\
\text { That could be injected into: }\end{array}$ & Gama 3 & Gama 4 \\
\hline $\begin{array}{l}\text { Volume of water above oil-water contact, } \\
\text { available for } \mathrm{CO}_{2}\end{array}$ & 266,952 & 72,100 \\
\hline $\begin{array}{l}\text { Volume of water below oil-water contact, } \\
\text { available for } \mathrm{CO}_{2}\end{array}$ & 76,568 & 2,149 \\
\hline Volume of oil above oil-water contact & $22,326,901$ & $6,124,377$ \\
\hline Mass of $\mathrm{CO}_{2}$ could be injected (tonnes) & $22,670,421$ & $6,273,045$ \\
\hline
\end{tabular}

\section{RESULTS AND CONCLUSIONS}

The primary goal is to inject into the Upper Miocene depleted sandstone oil reservoirs in the Ivanić Field. In two Upper Pannonian reservoirs, approximately 23 million and 6 million $\mathrm{t}$ (on 200 bars, $98^{\circ} \mathrm{C}$ ) of $\mathrm{CO}_{2}$ could be injected into the reservoir. Reactive minerals in the sandstones include numerous clay minerals like anorthite, zeolite, smectite, and others. Mineral storage can be an active process in transitional lithofacies like marly or clayey sandstones or siltstones, or in margin reservoirs where $\mathrm{CO}_{2}$ would be injected.

However, the estimation of volume kept by mineral sequestration is impossible to measure, even in the laboratory, because chemical processes in the subsurface require longer periods of time. Wilkinson et al. (2009) described Fizzy accumulation in the North Sea, rich in $\mathrm{CO}_{2}$, and in sublitharenite sandstones of the Rotliegend Group. The composition could be compared to the Sava Depression sandstones in this way: quartz $37-60 \%$ vs. $40-50 \%$, rock fragments $8-20 \%$ and dolomite $1-23 \%$ vs. dolomite and fragments $15-25 \%$, micas $0 \%$ vs. $10 \%$, K-feldspar $3-22 \%$ vs. $5-10 \%$. The porosity difference is significant and varies from $0-13 \%$ in Fuzzy and about $20 \%$ in the Ivanić Field. However, the mineral compositions and reactions are qualitatively similar.

$\mathrm{CO}_{2}$ in the sandstone reservoir will be permanently sequestered by mineral reactions producing carbonates (including dawsonite), usually at the expense of feldspars, although the role of mineral carbonation is sometimes overestimated (Wilkinson et al., 2009, and citations inside). In the Fizzy, the quantity of sequestrated $\mathrm{CO}_{2}$ is relatively small, with $0.5-30 \%$ in total in the dawsonite and possible dolomite cements, which are more likely to be at the lower end (Wilkinson et al., 2009). Using mineralogical analogies, depth $(2,300-2,450 \mathrm{~m}$ vs. $1600 \mathrm{~m})$, and temperature $\left(80-85 \%\right.$ vs. $\left.100^{\circ} \mathrm{C}\right)$, the percentage of total injected $\mathrm{CO}_{2}$ that could be permanently stored by carbonization into analysed sandstones in the Sava Depression could be a small percentage of the gross volume, especially because dawsonite is not proven. The large quantities of chlorite and glauconite, if present in sandstone, can fix significant $\mathrm{CO}_{2}$ in solid form. However, in the analysed subsurface such minerals are missed and could be detected only in some older, Upper Badenian sandstones.

Finally, minerals comprised of quartz, dolomite, and K-feldspar are favourable for testing such a process, especially because the sandstones may be up to $25 \%$ aluminosilicate minerals (Table 7). Dolomite rock fragments or detritus with abundant alkaline earth metals ( $\mathrm{Ca}$ and $\mathrm{Mg}$ ) could take part in mineral carbonation in general, but part of the carbonates in the sandstones would probably be dissolved after injection of $\mathrm{CO}_{2}$ into 
an acidic solution. Potential quantities for $\mathrm{CO}_{2}$ storage, per unit volume rock, could be obtained only after laboratory tests and monitoring of sandstone reservoirs saturated with $\mathrm{CO}_{2}$.

Acknowledgements. This work represents part of Ms. Novak's doctoral research and Ms. Husanović's graduate research. They participated in a multidisciplinary geological research project entitled "Development of geomathematical methods for analysis of Neogene depositional environments in the Croatian part of Pannonian Basin System" (head T. Malvić), which was financially supported by the University of Zagreb in the 2013 programme "Supporting of Researching 2". Part of subsurface model was permanently developed at the project "Stratigraphical and geomathematical research of petroleum geological systems in Croatia" (head J. Velić, no. 1951951293-0237), financed by the Croatian Ministry of Science, Education and Sport. The authors acknowledge reviewers (A. Wójcicki and two anonymous reviewers) and the editor, T.M. Peryt, for their valuable suggestions to improve the paper.

\section{REFERENCES}

Al-Jarba, M., Al-Anazi, B.D., 2009. A comparison study of the $\mathrm{CO}_{2}$-oil physical properties literature correlations accuracy using visual basic modelling technique. Oil and Gas Business, URL: http://www.ogbus.ru/eng/

Baines, S., Worden, R.H., 2004. The long-term fate of $\mathrm{CO}_{2}$ in the subsurface: natural analogues for $\mathrm{CO}_{2}$ storage. Geological Society Special Publications, 233: 59-85.

Bodor, M., Vlad, M., Balta, S., 2011. Overview of latest mineral carbonation techniques for carbon dioxide sequestration. Tehnomus, 18: 289-296.

Carroll, S.A., McNab, W.W., Torres, S.C., 2011. Experimental study of cement - sandstone/shale - brine $-\mathrm{CO}_{2}$ interactions. Geochemical Transactions, 12.

Gerdemann, S.J., O'Connor, W.K., Dahlin, D.C., Penner, L.R., Rush, H., 2007. Ex situ aqueous mineral carbonation. Environmental Science and Technology, 41: 2587-2593.

Goričnik, B., Domitrović, D., 2003. Laboratory research of $\mathrm{CO}_{2}$ EOR potential in the mature oilfields in the Republic of Croatia (in Croatian with English summary). Naftaplin, (1): 5-12.

Hansen, L.D., Dipple, G.M., Gordon, T.M., Kellett, D.A., 2005 Carbonated serpentinite (listwanite) at Atlin, British Columbia: a geological analogue to carbon dioxide sequestration. Canadian Mineralogist, 43: 225-239.

Hangx, S.J.T., Spiers, C.J., 2009. Coastal spreading of olivine to control atmospheric $\mathrm{CO}_{2}$ concentrations: a critical analysis of viability. International Journal of Greenhouse Gas Control, 3: 757-767.

Huijgen, W.J.J., Comans, R.N.J., 2005. Mineral $\mathrm{CO}_{2}$ Sequestration by Carbonation of Industrial Residues. ECN publication, www.ecn.nl

International Energy Agency. Greenhouse Gas R\&D Programme (IEA-GHG), 2000. $\mathrm{CO}_{2}$ storage as carbonate minerals, prepared by CSMA Consultants Ltd, PH3/17, Cheltenham, U.K.

Lackner, K.S., Butt, D.P., Wendt, C.H., 1997. Progress on binding $\mathrm{CO}_{2}$ in mineral substrates. Energy Conversion and Management, 38: 259-264

Liu, N., Liu, L., Qu, X., Yang, H., Wang, L., Zhao, S., 2011. Genesis of authigene carbonate minerals in the Upper Cretaceous reservoir, Honggang Anticline, Songliao Basin: a natural analogue for mineral trapping of natural $\mathrm{CO}_{2}$ storage. Sedimentary Geology, 237: 166-178.

Koenen, M., Wasch, L.J., Zalinge, M.E. van, Nelskamp, S., 2013. Werkendam, the Dutch natural analogue for $\mathrm{CO}_{2}$ storage long-term mineral reactions. Energy Procedia, 37: 3452-3460.

Malvić, T., 2008. Production of porosity map by kriging in sandstone reservoirs, case study from the Sava Depression. Kartografija i Geoinformacije, 9: 12-19.

Malvić, T., 2012. Review of Miocene shallow marine and lacustrine depositional environments in Northern Croatia. Geological Quarterly, 56 (3): 493-504.

Malvić, T., Velić, J., 2011. Neogene tectonics in Croatian part of the Pannonian Basin and reflectance in hydrocarbon accumula- tions. In: New Frontiers in Tectonic Research: at the Midst of Plate Convergence (ed. U. Schattner): 215-238. InTech, Rijeka.

McKelvy, M.J., Chizmeshya, A.V.G., Soignard, E., Marzke, R., Wolf, G.H., Béarat, H., Doss, B., 2006. Laboratory investigation of Fluid/Solid sequestration reaction processes under in situ sequestration process conditions, 41 . Proceedings of the 31 st International Technical Conference on Coal Utilization and Fuel Systems, Clearwater, 21-26 May, 2006: 384-400.

Novak, K., Malvić, T., Simon, K., 2012. Increased hydrocarbon recovery and $\mathrm{CO}_{2}$ management, a Croatian example. Environmental Earth Sciences, 68: 1187-1197.

Novak, K., Malvić, T., Velić, J., Simon, K., 2013. Increased hydrocarbon recovery and $\mathrm{CO}_{2}$ storage in Neogene sandstones, a Croatian example: part II. Environmental Earth Sciences, doi: $10.1007 / \mathrm{s} 12665-013-2756-6$

Novak Zelenika, K, 2012. Deterministic and Stochastic Geological Models of Upper Miocene Sandstones Reservoirs at the Kloštar Oil and Gas Field (in Croatian with English summary). Dissertation, University of Zagreb.

Novak Zelenika, K., Velić, J., Malvić, T., 2013. Local sediment sources and palaeoflow directions in Upper Miocene turbidites of the Pannonian Basin System (Croatian part), based on mapping of reservoir properties. Geological Quarterly, 57 (1): 16-30.

Novosel, D., 2009. The Effect of the Carbon Dioxide on the Tertiary Exploration Phase at the Ivanić Oil Field (in Croatian with English summary). Dissertation, University of Zagreb.

O'Connor, W.K., Dahlin, D.C., Nilsen, D.N., Rush, G.E., Walters, R.P., Turner, P.C., 2001. Carbon dioxide sequestration by direct mineral carbonation: results from recent studies and current status. DOE/ARC-2001-029. In: Proceedings of the First National Conference on Carbon Sequestration, National Energy Technology Laboratory, U.S. Department of Energy, Washington, 14-17 May, 2001.

O'Connor, W.K., Dahlin, D.C., Rush, G.E., Gerdemann, S.J., Penner, L.R., Nilsen, R.P., 2005. Aqueous Mineral Carbonation: Mineral Availability, Pretreatment, Reaction Parametrics, and Process Studies. DOE/ARC-TR-04-002, Albany Research Center, New York.

Penner, L.R., O'Connor, W.K., Dahlin, D.C., Rush, G.E., Gerdemann, S.J., 2004. Energy and economic considerations for ex-situ aqueous mineral carbonation, DOE/ARC-2004-028. U.S. Department of Energy, Albany Research Center, Oregon.

Perić, M., Kovač, S., 2003. Simulation study of enhanced oil recovery process by $\mathrm{CO}_{2}$ injection applying a multi-component COMP II (in Croatian with English summary). Naftaplin, (1): 13-25

Sečen, J., 2006. Enhance Oil Recovery Methods (In Croatian), 1st edn. INA-Naftaplin, Zagreb.

Seifritz, W., 1990. $\mathrm{CO}_{2}$ disposal by means of silicates. Nature, 345 : 486.

Sipilä, J., Teir, S., Zevenhoven, R., 2008. Carbon Dioxide Sequestration by Mineral Carbonation - Literature Review Update 2005-2007. Cbo Akademi Univ., Heat Engineering Lab. report VT 2008-1. 
Taber, J.J., Martin, F.D., Seright, R.S., 1997. EOR criteria revisited. Part 2: application and impact of oil prices. SPE Reservoir Engineering, 12: 199-205.

Tadej, J., Marić-Đureković, Ž., Slavković, R., 1996. Porosity, cementation, diagenesis and their influence on the productive capibility of sandstone reservoirs in the Sava Depression (Croatia). Geologia Croatica, 49: 311-316.

Velić, J., Malvić, T., Cvetković, M., 2011. Palinspastic reconstruction of synsedimentary tectonics of Neogene and Quaternary sediments in the Kloštar Field (Sava depression, Pannonian Basin, Croatia). Zeitschrift der Deutschen Gesellschaft für Geowissenschaften, 162: 193-201.

Vrbanac, B., Velić, J., Malvić, T., 2010. Sedimentation of deep-water turbidites in the SW part of the Pannonian Basin. Geologica Carpathica, 61: 55-69.

Wilkinson, M., Haszeldine, R.S., Fallick, A.E., Odling, N., Stoker, S.J., Gatliff, R.W., 2009. $\mathrm{CO}_{2}$-mineral reaction in a natural analogue for $\mathrm{CO} 2$ storage-implications for modeling. Journal of Sedimentary Research, 79: 486-494.

Xu, T., Apps, J.A., Pruess, K., 2004. Numerical simulation to study mineral trapping for $\mathrm{CO}_{2}$ disposal in deep aquifers. Applied Geochemistry, 19: 917-936.

Xu, T., Apps, J.A., Pruess, K., Yamamoto, H., 2008. Numerical modeling of injection and mineral trapping of $\mathrm{CO}_{2}$ with $\mathrm{H}_{2} \mathrm{~S}$ and $\mathrm{SO}_{2}$ in a Sandstone Formation. Chemical Geology, 242: 319-346.
Yajima, T., Okamoto, I., Ohsumi, T., Ninomiya, A., Yukihiro, M., Takayuki, K., 2006. Experimental studies of $\mathrm{CO}_{2}$ fixation by serpentinite. In: Proceedings of the 8th International Conference on Greenhouse Gas Control Technologies, Trondheim, 19-22 June, 2006.

Yu, M., Liu, L., Yu, Z., Liu, N., Yang, H., Qu, X., 2014. Dawsonite fixation of mantle $\mathrm{CO}_{2}$ in the cretaceous Songliao Basin, Northeast China: a natural analogue for $\mathrm{CO}_{2}$ mineral trapping in oilfields. International Geology Review, 56: 1792-1812.

Zevenhoven, R., Eloneva, S., Teir, S., 2006. Chemical fixation of $\mathrm{CO}_{2}$ in carbonates: routes to valuable products and long-term storage. Catalysis Today, 115: 73-79.

Zevenhoven, R., Teir, S., Eloneva, S., Aatos, S., Sorjonen-Ward, P., 2007. $\mathrm{CO}_{2}$ sequestration by carbonation of minerals and industrial by-products in Finland, 72. In: Proceedings of the R'07, Davos, 3-5 September, 2007.

Zevenhoven, R., Wiklund, A., Fagerlund, J., Eloneva, S., In't Veen, B., Geerlings, H., Mossel, G. van, Boerrigter, H., 2010. Carbonation of calcium-containing mineral and industrial by-products. Frontiers of Chemical Engineering in China, 4: 110-119.

Zevenhoven, R., Fagerlund, J., Björklöf, T., Mäkelä, M., Eklund, O., 2012. Carbon dioxide mineralisation and integration with flue gas desulphurisation applied to a modern coal-fired power plant. Proceedings of ECOS2012, Perugia, Italy, June, 2012 - Paper 179. 